\title{
Seasonal changes in the gelatinous zooplankton community and hydromedusa abundances in Korsfjord and Fanafjord, western Norway
}

\author{
Aino Hosia ${ }^{1, *}$, Ulf Båmstedt ${ }^{2}$ \\ ${ }^{1}$ University of Bergen, Department of Biology, PO Box 7800, 5020 Bergen, Norway \\ ${ }^{2}$ Umeå University, Department of Ecology and Environmental Sciences and Umeå Marine Sciences Centre, Norrbyn, \\ 91020 Hörnefors, Sweden
}

\begin{abstract}
Quantitative seasonal studies on gelatinous zooplankton in Norwegian fjords are scarce. We recorded the quantitative composition of the gelatinous zooplankton community in Korsfjord and Fanafjord during 1 yr. Thirty-six species or genera of hydromedusae, 7 species of siphonophores, 4 species of ctenophores and 2 species of scyphomedusae were recorded. Aglantha digitale was numerically dominant in both fjords. A separate video-profiling study on the vertical distribution of fully grown specimens of this species was made in Korsfjord and the adjacent Bjørnafjord. Our data suggest 2 A. digitale generations $\mathrm{yr}^{-1}$, with relatively low importance of the latter generation. The overwintering strategy includes autumn growth to full size and distribution at intermediate depth, mainly between 200 and $300 \mathrm{~m}$. Siphonophores were prominent in the more oceanic Korsfjord, while Fanafjord was characterized by meroplanktonic hydromedusae. More species were recorded from Korsfjord, which may be partly attributed to the larger volume sampled and the higher probability of encountering oceanic visitors in this fjord. Korsfjord also harbored a community of deep-water hydromedusae absent from Fanafjord. The gelatinous community of both fjords was most numerous and species-rich from April to June. Spring maximum densities were higher in Fanafjord. During winter, gelatinous zooplankton was more abundant in Korsfjord, with eudoxids of Dimophyes arctica and Lensia conoidea forming the bulk of the community. Hydromedusa species appeared sequentially and differed in terms of maximum abundance attained and length of their presence in the plankton. Multivariate analyses revealed a clear seasonal succession for the gelatinous community of both fjords.
\end{abstract}

KEY WORDS: Gelatinous zooplankton · Seasonality $\cdot$ Hydromedusae $\cdot$ Aglantha digitale $\cdot$ Fjords · Norway

Resale or republication not permitted without written consent of the publisher

\section{INTRODUCTION}

When abundant, gelatinous predators can have profound effects on the plankton community through direct predation and competition for food (Alldredge 1984, Matsakis \& Conover 1991, Behrends \& Schneider 1995, Nicholas \& Frid 1999) as well as trophic cascading effects (Verity \& Smetacek 1996, Schneider \& Behrends 1998). However, due to the highly seasonal occurrence of many gelatinous species, their structuring effect on the pelagic community is often temporary (Matsakis \& Conover 1991, Behrends \& Schneider
1995). In order to quantify the role of gelatinous predators in an ecosystem, knowledge of their seasonality is of paramount importance.

Meroplanktonic hydromedusae are a major component of gelatinous zooplankton in the neritic zone. The planktonic medusae are usually budded off by a benthic hydroid, and are generally only found in the water column seasonally. The medusae of different species tend to appear in the plankton in a more or less predictable succession (Mills 1981, 1993, Ballard \& Myers 2000).

Several earlier studies addressed the composition of gelatinous fauna (especially hydromedusae) along the 
Norwegian coast (Kramp \& Damas 1925, Runnström 1931, Rees 1952, Kramp 1959, Rasmussen 1971), but none of these represents a truly quantitative seasonal study for the whole gelatinous community. In the present paper we describe and compare seasonal changes in the gelatinous zooplankton community of 2 adjacent fjords, Korsfjord and Fanafjord, on the west coast of Norway, and quantify the seasonal occurrence and abundance of hydromedusae in these fjords.

Korsfjord is a large fjord with a $250 \mathrm{~m}$ sill and a maximum depth of $690 \mathrm{~m}$. It has numerous secondary connections with the sea through an archipelago in the southwest, as well as connections to further fjord systems in the south and, to

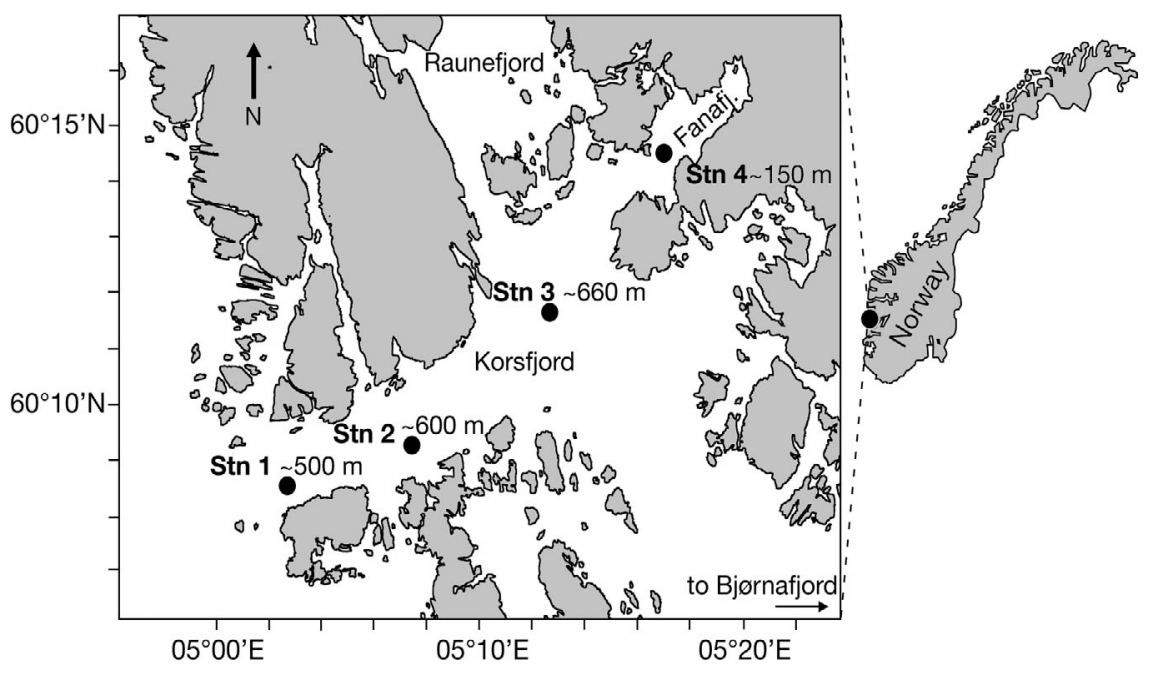

Fig. 1. Korsfjord area and sampled stations a lesser extent, north (see Fig. 1). The deep-water pelagic ecology of Korsfjord was extensively studied in the 1960s and 1970s (see Matthews \& Sands 1973) and the hydrography of the fjord has been described by Bakke \& Sands (1977) as well as Matthews \& Sands (1973). The shallower (maximum depth ca. $155 \mathrm{~m}$ ) and smaller Fanafjord is separated from Korsfjord by a $90 \mathrm{~m}$ sill (Wassmann 1984). The deep water in both Fanafjord and Korsfjord is frequently renewed by Atlantic water from the continental shelf, characterized by a salinity $>35$ (Wassmann 1984).

\section{MATERIALS AND METHODS}

Sampling and processing of material. Zooplankton net sampling was performed during 2003. Three stations in Korsfjord and one in Fanafjord (Fig. 1) were sampled 1 to 2 times $\mathrm{mo}^{-1}$, in total 20 times over the year, using a WP3 net with $300 \mu \mathrm{m}$ mesh size and a nonfiltering cod-end. The net was hauled vertically from approximately $20 \mathrm{~m}$ above the bottom to the surface at ca. $0.3 \mathrm{~m} \mathrm{~s}^{-1}$. A CTD instrument (SAIV A/S, SD204) recording temperature and salinity was attached to the net. The collected material was immediately concentrated by using a $300 \mu \mathrm{m}$ meshed sieve and preserved with borate-buffered $4 \%$ formalin in seawater. Gelatinous animals were identified and enumerated using a stereomicroscope. All animals from smaller samples were counted. The largest samples were split in half using a Folsom splitter. Animals were then counted from one half, while the other half was scanned for additional species. Siphonophores were rarely collected intact, so their numbers were estimated from the parts found in the samples (authors' unpubl. data). The enumeration of physonect siphono-

phores was primarily based on the number of pneumatophores and intact colonies. When this was not feasible, nectophore count was used to estimate the number of colonies. Anterior nectophores and eudoxids were counted for calycophoran siphonophores. Abundances per volume were calculated based on the length $(\mathrm{m})$ of the haul and assuming $100 \%$ filtering efficiency of the net. When present, at least the first 10 encountered specimens of each species were measured. Height of the bell was measured for prolate medusae and diameter of the bell for oblate medusae. Presence or absence of gonads was noted for Aglantha digitale.

An additional study on the vertical distribution of Aglantha digitale was made in Korsfjord and the adjacent Bjørnafjord $\left(60^{\circ} 05.50^{\prime} \mathrm{N}, 5^{\circ} 30.00^{\prime} \mathrm{E}\right)$ during October 2004 and May 2005. A remotely operated vehicle (ROV) with video camera and illumination was used (see Båmstedt \& Youngbluth 2000) in vertical video transects throughout the water column. The system was configured for macroplankton recording, and we estimated that the lower size limit for enumeration of $A$. digitale was ca. $1 \mathrm{~cm}$ bell height. Thus, our results show the vertical distribution of adult medusae only. The quantification was based on an area of view of $1.2 \mathrm{~m}^{2}$, and the abundance was integrated over $10 \mathrm{~m}$ intervals.

Data analyses. Data analyses were performed with PRIMER version 5.2.9 software (PRIMER-E). To begin with, a matrix of Bray-Curtis similarities between all samples from all 4 stations was created. Abundances were 4 th root-transformed to take into account the rarer species. Analysis of similarities (ANOSIM) was then used to test for differences between samples from the different stations. Since the ANOSIM test showed that there were no differences among the Korsfjord stations, but that the Fanafjord station significantly dif- 
fered from all of them, the Korsfjord stations were pooled and the averages from them were used in all subsequent analyses. The similarity percentages (SIMPER) routine was used to explore the contribution of different species to the dissimilarity between the 2 fjords. Separate matrices of Bray-Curtis similarities between sampling dates were constructed for Korsfjord and Fanafjord in order to study the seasonal succession. To calculate the similarities between the sampling dates, the abundance numbers were 4 th root-transformed to take into account the rarer species. Data from both fjords were included in the construction of a further matrix of Bray-Curtis similarities between the species. When calculating the similarities between species, those contributing $<4 \%$ of the total abundance were removed from the analysis and the untransformed data were standardized by dividing the species-specific abundances by the total number of animals in the sample and multiplying by 100 (Clarke \& Warwick 2001). Hierarchical clustering with group average linkage and nonmetric multidimensional scaling (NMDS) were applied to all similarity matrices.

The different developmental and reproductive stages of any given species (e.g. eudoxid and polygastric colonies of calycophoran siphonophores; Aglantha digitale with and without gonads) were combined in the analyses in order to exclude the effect of growth and development within species. The results from these analyses therefore reflect changes in community structure rather than changes within individual species populations.

\section{RESULTS}

\section{Hydrography}

Seasonal changes and stratification of both temperature and salinity were pronounced in the surface waters (Fig. 2). During the summer months, a seasonal thermocline developed at ca. 30 to $40 \mathrm{~m}$. Through fall and winter, the warm surface water was gradually mixed deeper and a reverse stratification developed. The surface temperatures in Fanafjord showed a slightly wider range than in Korsfjord, reaching a minimum of 3.1 and maximum of $18.9^{\circ} \mathrm{C}$. Salinity was lowest in the stratified surface waters, dropping to $<30$ psu during the summer months. The position of the $35 \mathrm{psu}$ isohaline fluctuated between ca. 50 and $300 \mathrm{~m}$. Conditions below $300 \mathrm{~m}$ were relatively stable, with the salinity $>35$ psu and temperature around 7 to $8^{\circ} \mathrm{C}$. In the shallower Fanafjord, seasonal fluctuations in temperature and salinity were observed all the way to the bottom. The CTD data from 4 dates (27 to 28 May, 7 to 8 July, 5 to 6 August and 18 August) were removed from the analyses, since a different CTD unit, not calibrated with the primary unit, was used on these dates. Due to low sampling frequency, it is difficult to define any occasions with inflow of Atlantic water from outside the fjord. However, a definite increase in the salinity in the main basin was observed in December, interrupting a situation in November with gradual mixing of surface water down in the water column.

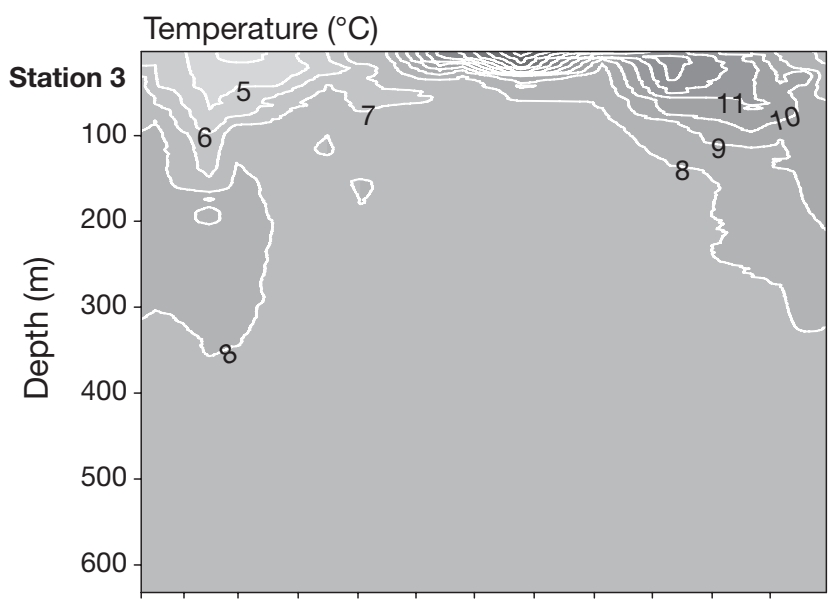

Salinity (PSU)
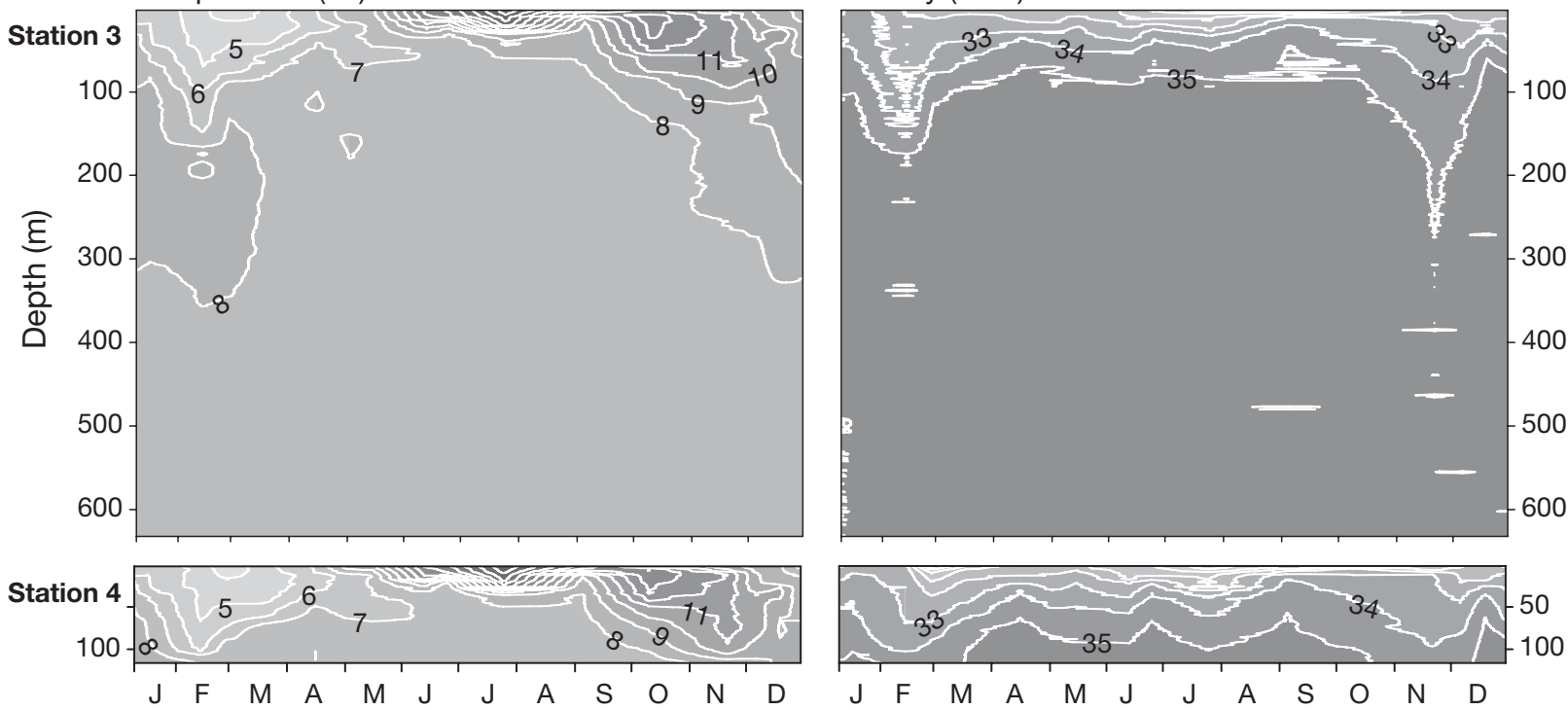

Fig. 2. Contour plots of temperature $\left({ }^{\circ} \mathrm{C}\right.$ ) and salinity (psu) at Stns 3 (Korsfjord) and 4 (Fanafjord). Data from Stns 1 and 2 are not shown, since they were similar to Stn 3 


\section{Observed species}

A total of 49 species or genera were identified during the study (Table 1). This number excludes the groups Hydractinia spp. and 'indet. corynid'. These groups consisted of juvenile individuals that could not be identified to species, but most likely belonged to those Hydractinia and corynid species mature individuals of which were also present in the samples. Hydromedusae were the most diverse group with 36 species or genera. Seven species of siphonophores, 4 species of ctenophores and 2 species of scyphozoan medusae were also recorded.

Hydromedusae identified to genus level only included Obelia spp. and Zanclea sp., for which medusae cannot be reliably identified to species level (Bouillon et al. 2004) as well as Bougainvillia spp. All Bougainvillia specimens apart from B. muscoides were pooled, as they included mostly immature medusae difficult to assign to species based on the preserved material. However, tentative identification suggested that the group contained specimens of $B$. superciliaris (L. Agassiz, 1849), B. principis (Steenstrup, 1850) and B. ramosa (van Beneden, 1844), all of which have previously been recorded in the vicinity of Bergen (Kramp \& Damas 1925, Rasmussen 1971). Six siphonophore specimens from Korsfjord were identified as Sphaeronectes sp. Their nectophores had looping radial canals similar to $S$. irregularis, $S$. gamulini and $S$. fragilis (Carré 1968), but their vertically oriented, globular somatocyst with a short but distinct stalk did not fit the description of any of these species.

The vast majority of the species we observed are established constituents of the gelatinous fauna of the region. The notable exceptions were the 2 new species of hydromedusae discovered during the project, Foersteria quadrata and Parateclaia norvegica (Hosia \& Pagès 2007). We also confirmed the presence of Hydractinia areolata (was Podocoryna hartlaubi) in
Table 1. Species collected from Korsfjord (Kors) and Fanafjord (Fana). -: species not found

\begin{tabular}{|c|c|c|c|}
\hline \multirow[t]{2}{*}{ Species } & \multicolumn{3}{|c|}{ No. of specimens collected } \\
\hline & Total & Kors & Fana \\
\hline \multicolumn{4}{|l|}{ Hydromedusae } \\
\hline Coryne eximia Gaertner, 1774 & 54 & 35 & 19 \\
\hline Dipurena gemmifera (Forbes, 1848) & 1450 & 45 & 1405 \\
\hline Sarsia tubulosa (M. Sars, 1835) & 31 & 11 & 20 \\
\hline Indet. corynid & 233 & 4 & 229 \\
\hline Euphysa aurata Forbes, 1848 & 615 & 327 & 288 \\
\hline Euphysa tentaculata Linko, 1905 & 2 & 2 & - \\
\hline Plotocnide borealis Wagner, 1885 & 1 & - & 1 \\
\hline Corymorpha nutans M. S. Sars, 1835 & 419 & 267 & 152 \\
\hline Margelopsis hartlaubi Browne, 1903 & 704 & 696 & 8 \\
\hline Zanclea sp. & 6 & 6 & - \\
\hline Hydractinia areolata (Alder, 1862) & 34 & 7 & 27 \\
\hline Hydractinia borealis (Mayer, 1900) & 18 & 13 & 5 \\
\hline Hydractinia carnea Sars, 1846 & 34 & 20 & 14 \\
\hline Hydractinia spp. & 23 & 3 & 20 \\
\hline Rathkea octopunctata (Sars, 1835) & 514 & 282 & 232 \\
\hline Bougainvillia muscoides (Sars, 1846) & 50 & 29 & 21 \\
\hline Bougainvillia spp. & 96 & 58 & 38 \\
\hline Lizzia blondina Forbes, 1848 & 115 & 40 & 75 \\
\hline Leuckartiara octona (Fleming, 1823) & 2 & 2 & - \\
\hline Neoturris pileata (Forskal, 1775) & 2 & 2 & - \\
\hline Bythotiara murrayi Gunther, 1903 & 7 & 7 & - \\
\hline Calycopsis simplex Kramp \& Damas, 1925 & 1 & 1 & - \\
\hline Modeeria rotunda (Quoy \& Gaimard, 1827) & 2 & 2 & - \\
\hline Melicertum octocostatum (Sars, 1835) & 10 & 6 & 4 \\
\hline Laodicea undulata (Forbes \& Goodsir, 1851) & 2 & 2 & - \\
\hline Ptychogena crocea Kramp \& Damas, 1925 & 13 & 13 & - \\
\hline Foersteria quadrata Hosia \& Pagès, 2007 & 73 & 73 & - \\
\hline Mitrocomella polydiademata (Romanes, 1876) & 25 & 24 & 1 \\
\hline Tiaropsis multicirrata (Sars, 1835) & 99 & 61 & 38 \\
\hline Parateclaia norvegica Hosia \& Pagès, 2007 & 6 & 6 & - \\
\hline Clytia hemisphaerica (Linnaeus, 1767) & 603 & 282 & 321 \\
\hline Clytia islandica (Kramp, 1919) & 1 & 1 & - \\
\hline Obelia spp. & 7376 & 5406 & 1970 \\
\hline \multicolumn{4}{|l|}{ Octophialucium funerarium } \\
\hline (Quoy \& Gaimard, 1827) & 3 & 3 & - \\
\hline Eutonina indicans (Romanes, 1876) & 20 & 4 & 16 \\
\hline Proboscidactyla stellata (Forbes, 1846) & 3 & 1 & 2 \\
\hline Aglantha digitale (Muller, 1776) & 20998 & 17799 & 3199 \\
\hline Homoeonema platygonon Browne, 1903 & 192 & 191 & 1 \\
\hline \multicolumn{4}{|l|}{ Siphonophora } \\
\hline Apolemia uvaria (Lesueur, 1815) & 4 & 3 & 1 \\
\hline Agalma elegans (M. Sars, 1846) & 6 & 6 & - \\
\hline Cordagalma ordinata (Totton, 1932) & 28 & 27 & 1 \\
\hline Nanomia cara A. Agassiz, 1865 & 902 & 851 & 59 \\
\hline Dimophyes arctica (Chun, 1897) & 9180 & 9167 & 13 \\
\hline Lensia conoidea (Keferstein \& Ehlers, 1860) & 7311 & 7209 & 102 \\
\hline Sphaeronectes sp. & 6 & 6 & - \\
\hline \multicolumn{4}{|l|}{ Scyphozoa } \\
\hline Aurelia aurita (Linnaeus, 1758) & 42 & - & 42 \\
\hline Cyanea capillata (Linnaeus, 1758) & 2 & 2 & - \\
\hline \multicolumn{4}{|l|}{ Ctenophora } \\
\hline Pleurobrachia pileus (Müller, 1776) & 261 & 143 & 118 \\
\hline Indet. cydippid & 194 & 169 & 25 \\
\hline Beroe sp. & 6716 & 6536 & 180 \\
\hline Bolinopsis infundibulum (O. F. Muller, 1776) & \multicolumn{3}{|c|}{ Not quantified } \\
\hline
\end{tabular}


Korsfjord, tentatively proposed by Rasmussen (1971). The English Channel has previously been given as the northern limit for the distribution of $H$. areolata (Kramp 1959). Euphysa tentaculata is a primarily arctic species with a relict population in the Kattegat (Kramp 1959). While we only collected 2 specimens of E. tentaculata from Korsfjord, Rasmussen (1971) found several, including newly hatched medusae that suggested that reproduction was taking place at least locally.

Our samples also contained a probably undescribed ctenophore species, referred to as 'indet. cydippid'. It was collected throughout the year from Korsfjord, as well as during the spring from Fanafjord. The species is also often observed at mesopelagic depths in western Norwegian fjords during ROV dives (authors' unpubl. data). It seems to grow to ca. $1.5 \mathrm{~cm}$ and is reasonably sturdy, since at least some of the animals stayed relatively intact during net collection and preservation. The animal is whitish, with yellowish or pinkish elongated tentacle bulbs. The statocyst is located at the bottom of a short funnel. The ctenes are relatively large with respect to the size of the animal. The very prominent ctene rows are of equal length, starting from the aboral end and extending for $2 / 3$ to $4 / 5$ of the distance to the mouth. There are 2 deep clefts extending from the aboral end for more than half the length of the animal on the sides from which the tentacles emerge. In live animals (ROV footage), prominent horns can be seen above the mouth. Net-caught specimens had generally lost their tentacles, but ROV footage shows that the tentacles can be extended for several times body length and are usually held parallel to the body, emerging from the clefts close to each other at the aboral end. Unfortunately, no specimens were caught in a good enough condition to give a more detailed description of the species.

\section{Species abundance and occurrence}

Aglantha digitale (O. F. Müller, 1766) was a dominant gelatinous zooplankter in both fjords (Table 1, Figs. 3 \& 4). It was present throughout the year in Korsfjord and from January to September in Fanafjord. Overwintering individuals were only encountered in Korsfjord. Small individuals were common during March through July (Figs. 5 \& 6). The main peak in A. digitale abundance was observed from April to early May (Fig. 5). There was a secondary peak in mid-June, consistent over all stations. This second peak coincided with a drop in the average size of A. digitale (Figs. 5 \& 6).

The siphonophores Dimophyes arctica, Lensia conoidea and Nanomia cara as well as the ctenophore

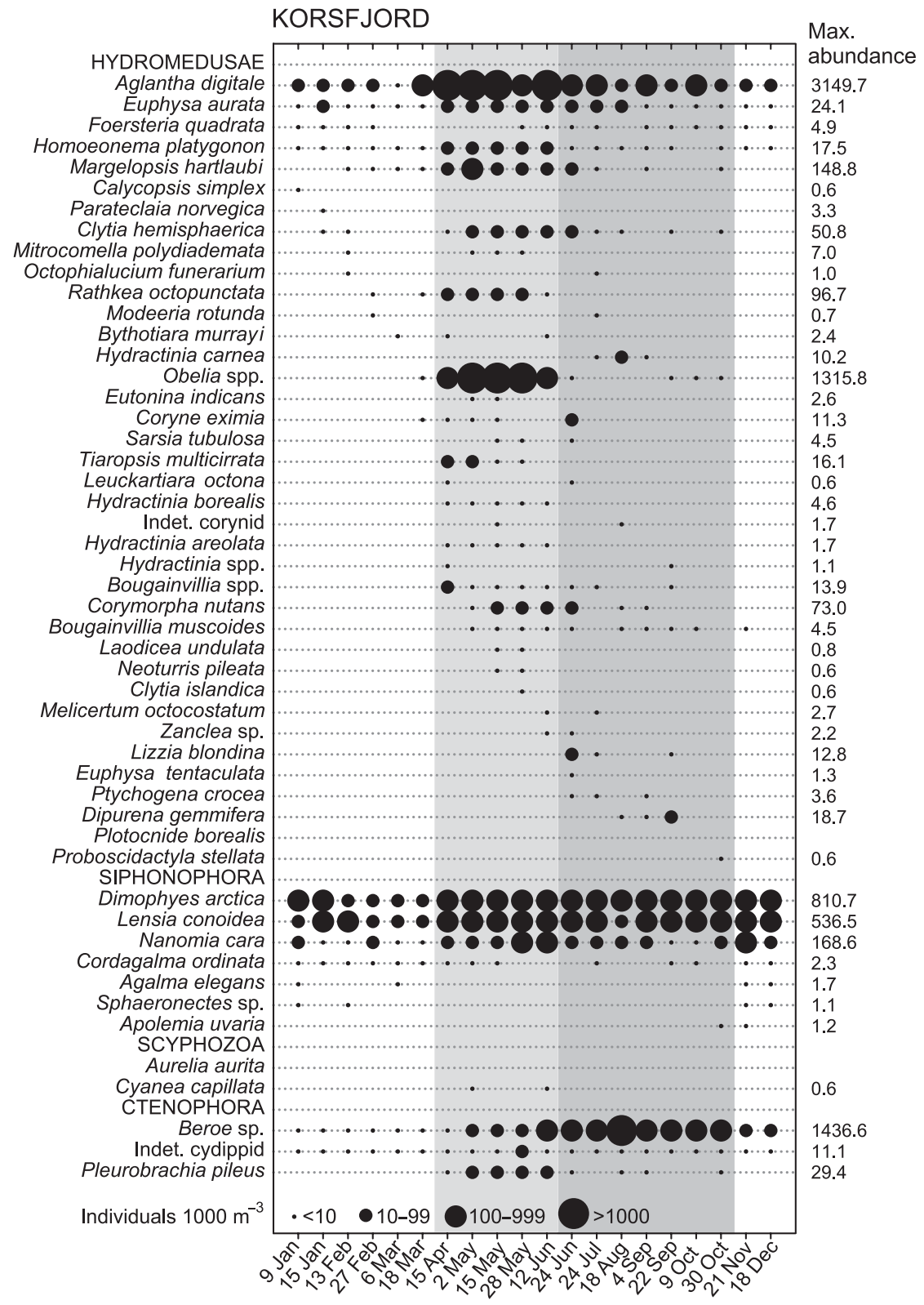

Fig. 3. Seasonal occurrence and abundance of gelatinous zooplankton species in Korsfjord. Note that $x$-axis is not linear. Bubble size reflects the general level of abundance at a logarithmic scale, with the increasing sizes indicating $<10$, 10-99, 100-999 and >1000 ind. $1000 \mathrm{~m}^{-3}$. Grey-scale shading identifies the seasonal clusters identified by hierarchical clustering (see Fig. 11). Maximum abundance observed is given for each species 


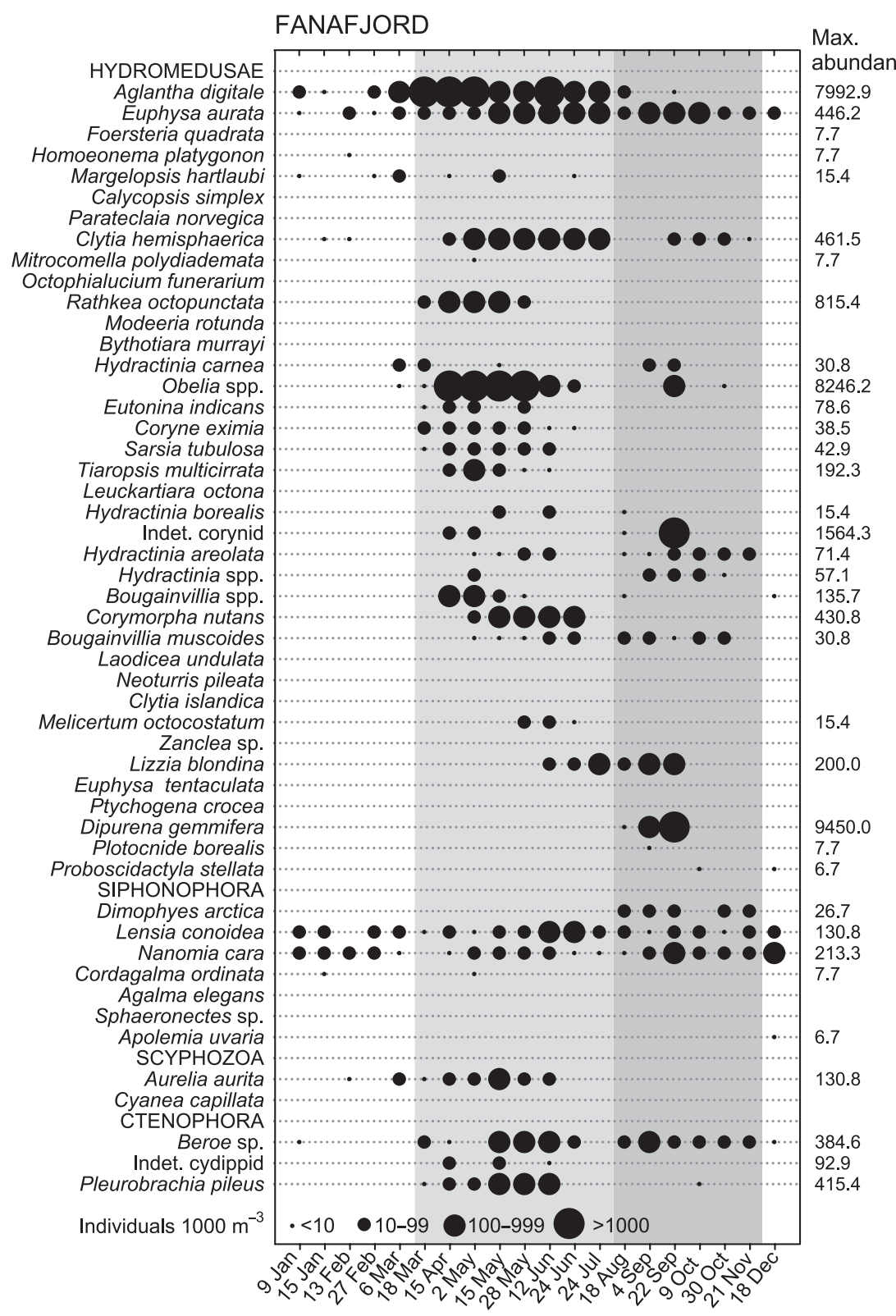

Fig. 4. Seasonal occurrence and abundance of gelatinous zooplankton species in Fanafjord. Note that $x$-axis is not linear. Bubble size reflects the general level of abundance at a logarithmic scale, with the increasing sizes indicating $<10,10-99,100-999$ and $>1000$ ind. $1000 \mathrm{~m}^{-3}$. Grey-scale shading identifies the seasonal clusters identified by hierarchical clustering, with the exception of 13 February, which is included in the winter group (see Fig. 11). Maximum abundance observed is given for each species

Beroe sp. were also prominent members of the gelatinous community (Figs. 3 \& 4, Table 1). These species are holoplanktonic, and were found in the plankton throughout the year, albeit with seasonal changes in their abundance. Siphonophores and Beroe sp. were more common in Korsfjord than in Fanafjord. The holoplanktonic trachymedusa Homoeonema platygonon and meroplanktonic anthomedusa Euphysa aurata were also present in the plankton throughout the year, the latter being more abundant of the two (Figs. 3, 4 \& 7). Foersteria quadrata, Margelopsis hartlaubi and Clytia hemisphaerica occurred for large parts of the year, but with a few months' absence occurring during early spring for the former (see Hosia \& Pagès 2007 for discussion) and winter for the latter two (Figs. 3, $4 \& 7$ ). The rest of the hydromedusae were observed in the plankton for shorter periods. About onethird of the species were encountered $<10$ times during the year (Table 1). Most of these rare species were collected from Korsfjord. Meroplanktonic Obelia spp. and Dipurena gemmifera reached the highest transient abundances recorded during the study: 8.2 and 9.5 ind. $\mathrm{m}^{-3}$, respectively, in Fanafjord (Fig. 7).

No detailed seasonal abundance is given for the ctenophores, since these were often badly damaged during collection and fixation, and the samples contained significant numbers of specimens that could not be reliably identified or enumerated. The ctenophore abundances were therefore likely to be severely underestimated. The approximate timing of maximum abundances for Beroe sp., Pleurobrachia pileus and the unidentified cydippid can be seen in Figs. 3 \& 4. The lobate ctenophore Bolinopsis infundibulum was also often observed, but could not be enumerated from the net samples due to disintegration of the animals.

\section{Vertical distribution of Aglantha digitale}

An abundant population of large (bell height $>1 \mathrm{~cm}$ ) Aglantha digitale was present in Bjørnafjord both on 30 October 2004 and 22 May 2005, with an average abundance of 0.37 and 0.51 ind. $\mathrm{m}^{-3}$, respectively. Corresponding abundances for Korsfjord were 0.25 and 0.02 ind. $\mathrm{m}^{-3}$, respectively. Large $A$. digitale were almost completely absent from the water shallower than $220 \mathrm{~m}$, but showed a strong aggregation just below this depth (Fig. 8). The peak abundances were similar in May and October in Bjørnafjord, and in October in Korsfjord: 2.9, 3.4 and 2.9 ind. $\mathrm{m}^{-3}$, respectively; whereas Korsfjord in May showed a peak abundance of only 0.3 ind. $\mathrm{m}^{-3}$ (Fig. 8). 


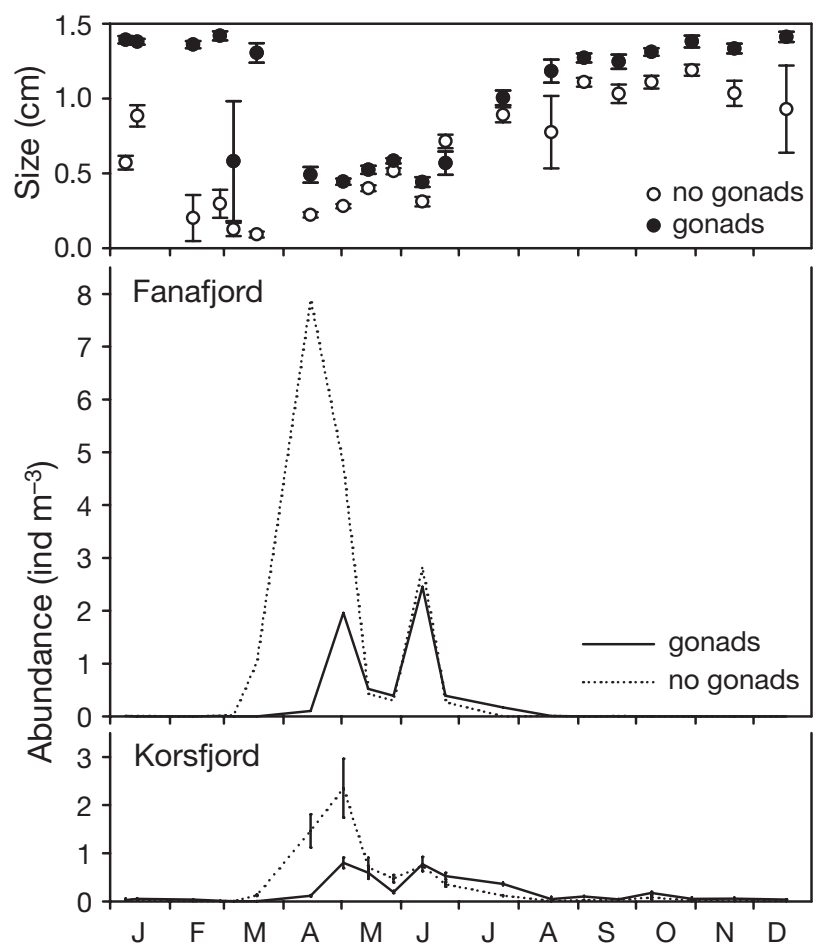

Fig. 5. Aglantha digitale. Seasonal abundance and size distribution in Korsfjord and Fanafjord. Average and SE shown for abundance in Korsfjord and size data. Size data are combined for all stations

\section{Gelatinous community}

There were significant differences in species composition between the station in Fanafjord and those in Korsfjord (ANOSIM, p < 0.001), but not among the Korsfjord stations. The data from the Korsfjord stations were therefore pooled and averages from them used for further analysis and comparisons between Korsfjord and Fanafjord.

A total of 47 species were recorded from Korsfjord and 33 from Fanafjord (Table 1). In both fjords, the gelatinous community was in terms of species count at its most diverse from April to June (Fig. 9). While the maximum number of species observed during the spring was similar in both fjords, the species count during the winter minimum tended to be higher in Korsfjord. The species responsible for the higher winter species count in Korsfjord included infrequently observed siphonophores (Agalma elegans, Apolemia uvaria, Sphaeronectes irregularis) as well as some deep-water hydromedusae (Foersteria quadrata, Homoeonema platygonon, Calycopsis simplex).

The total abundance of gelatinous zooplankton also peaked in April to June, with the maximum densities in Fanafjord about 3 times as high as those in Korsfjord (Fig. 9). This spring peak was mostly due to the appear-

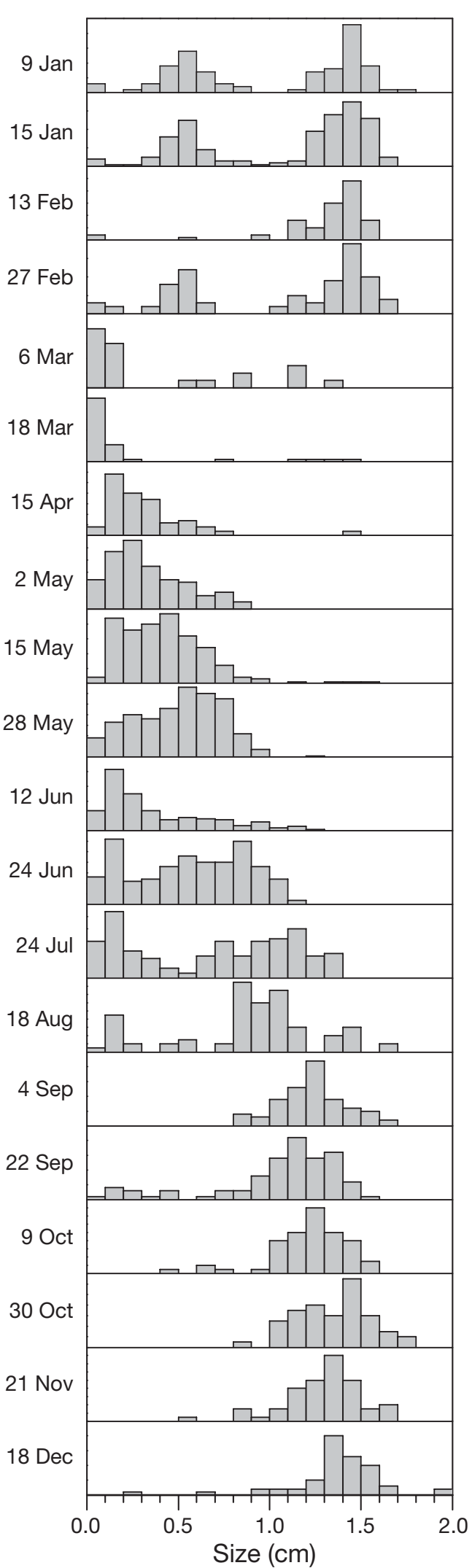

Fig. 6. Aglantha digitale. Seasonal size distribution. The $y$-axes are relative 

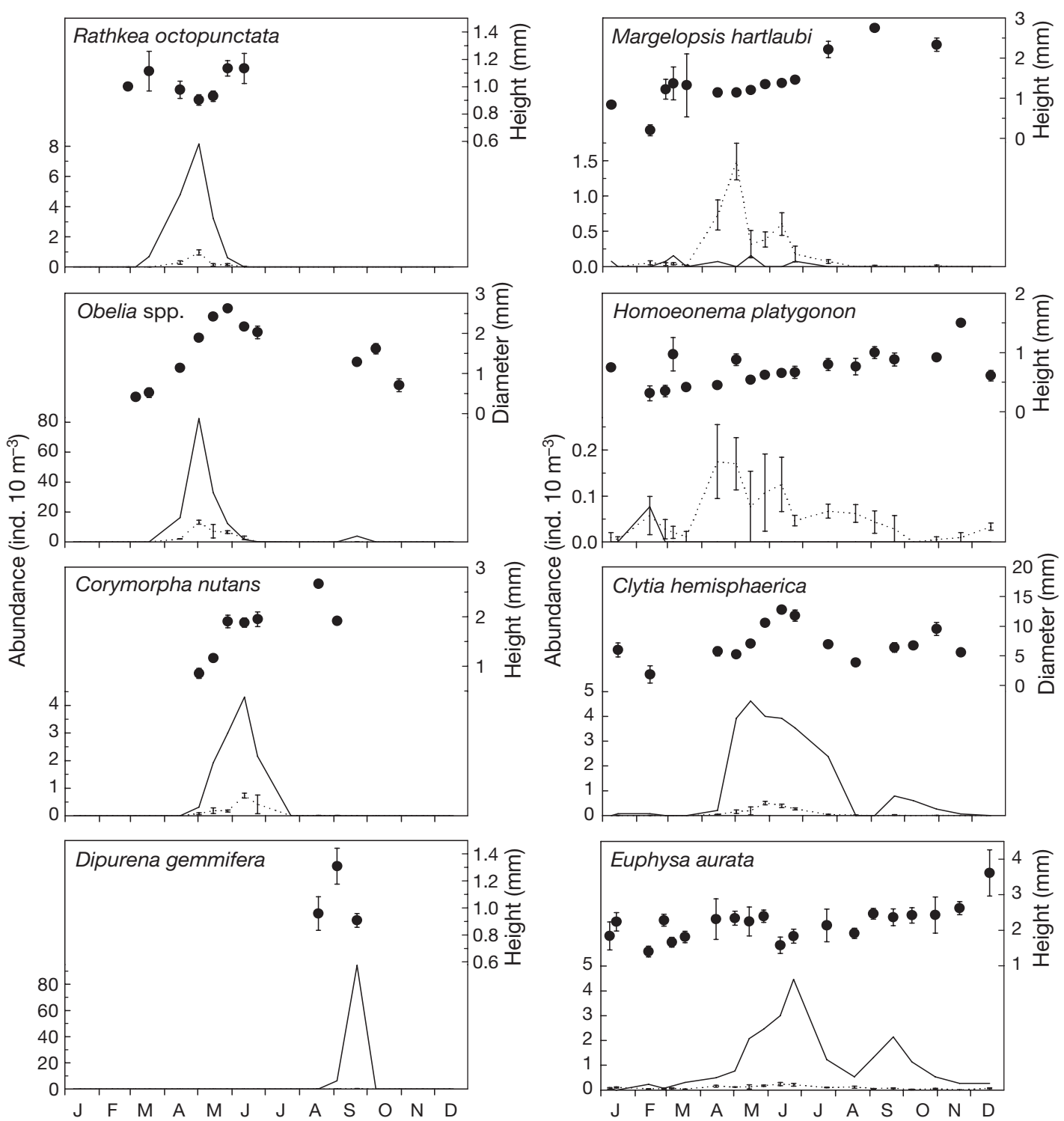

Fig. 7. Seasonal abundance and size distribution of common hydromedusae (apart from Aglantha digitale) in Korsfjord and Fanafjord. Solid line shows abundances in Fanafjord, dotted line Korsfjord. Average and SE presented for abundance in Korsfjord and size data. Size data combined for both fjords. Note the varying scales of the $y$-axes

ance of several species of meroplanktonic hydromedusae in the water column as well as an increasing population of Aglantha digitale. In Fanafjord, a second peak in medusa abundance and species count was observed in September, with Dipurena gemmifera accounting for the bulk of the medusae. During the winter months, the abundance of gelatinous zooplankton was somewhat higher in Korsfjord than in Fanafjord (Fig. 9). The bulk of this winter population in Korsfjord was made up by eudoxids of the diphyid siphonophores Dimophyes arctica and Lensia conoidea, which were much less numerous in Fanafjord.

Looking at the species responsible for the dissimilarity between Korsfjord and Fanafjord (Table 2), we find that Korsfjord was characterized by relatively high abundances of the diphyid siphonophores Dimophyes arctica and Lensia conoidea as well as the ctenophore Beroe sp. Korsfjord also harbored a community of deep-water hydromedusae, absent in the shallower Fanafjord. The gelatinous community in Fanafjord was characterized by a medley of meroplanktonic hydromedusae. The ctenophore Pleurobrachia pileus and, somewhat surprisingly, the holoplanktonic Aglantha digitale, were also more prevalent in Fanafjord than in Korsfjord. A similar picture emerges when examining the 3 species associations revealed by hierarchical clustering of the common species (Fig. 10). The first cluster contained siphonophores, deep-water medusae 

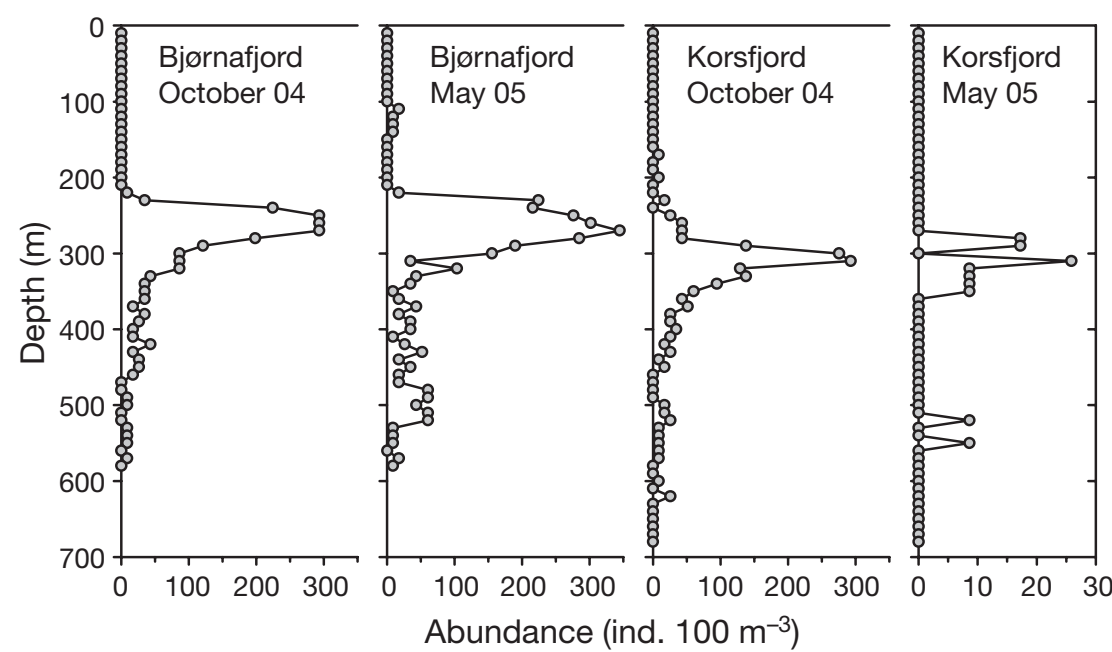

Fig. 8. Aglantha digitale. Vertical distribution of large $(>1 \mathrm{~cm}$ bell height) specimens in Bjørnafjord and Korsfjord 30-31 October 2004 and 21-22 May 2005. Results are calculated from vertical video transects and the abundance integrated over $10 \mathrm{~m}$ intervals

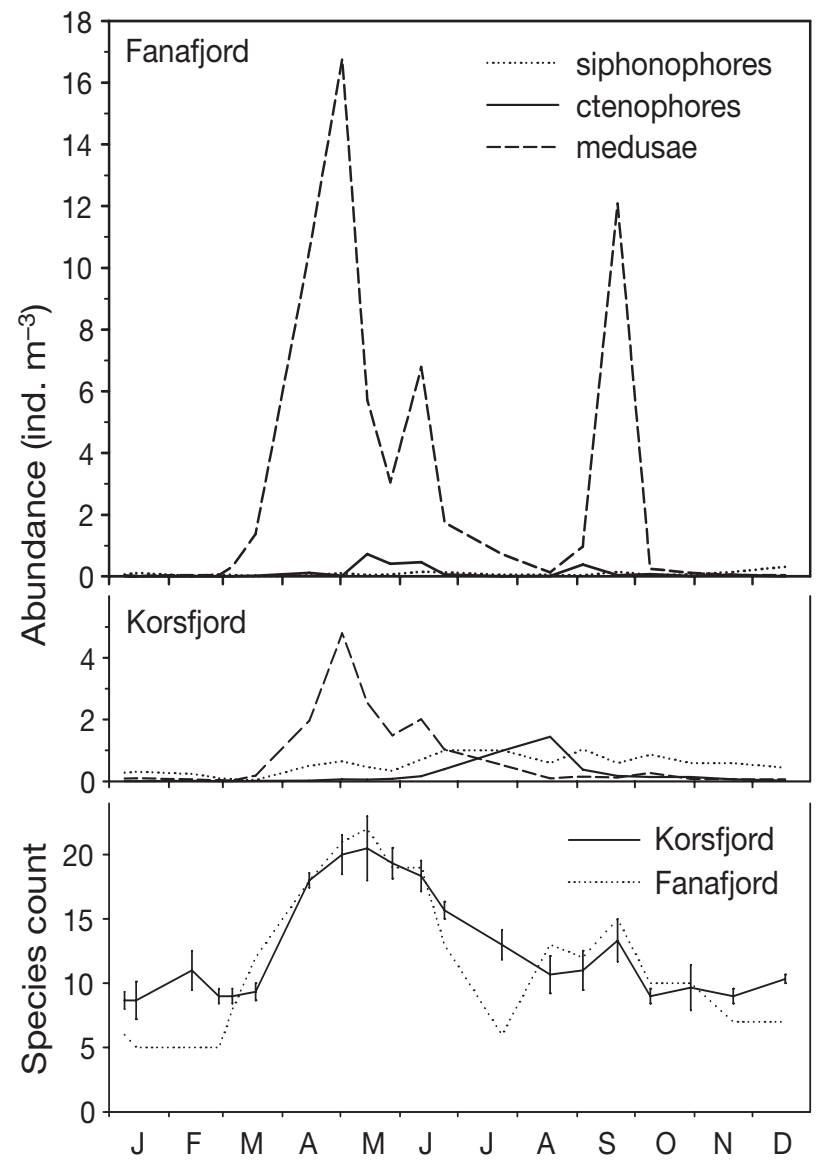

Fig. 9. Seasonal changes in the total abundances (ind. $\mathrm{m}^{-3}$ ) of medusae, siphonophores and ctenophores in Korsfjord and Fanafjord; seasonal changes in species richness in Korsfjord and Fanafjord. Values for Korsfjord are averages from Stns 1 to 3; SE shown for species count in Korsfjord and Beroe sp., all species that were more common in Korsfjord and either holoplanktonic or otherwise found in the plankton for most of the year. The species in the 2 remaining clusters were generally more affiliated with Fanafjord, with species in the second cluster tending to attain peak abundances earlier in the year than those in the third cluster.

Hierarchical clustering and NMDS plots of samples from different dates revealed a clear seasonal succession for the gelatinous community of both Korsfjord and Fanafjord (Fig. 11). Hierarchical clustering grouped the samples from both fjords according to season, with a winter cluster, a spring-summer cluster and a summer-fall cluster (with the exception of the sample from 13 February from Fanafjord, which was grouped alone). Samples from Fanafjord tended to be less similar among each other than the samples from Korsfjord (data not shown), and the succession from sample to sample was less straightforward. The winter samples from both fjords were generally characterized by low abundances and species count. In Korsfjord, siphonophores were numerically dominant and relatively diverse during this period. During spring-summer, both fjords were numerically dominated by Aglantha digitale and Obelia spp., with several other hydromedusae and Pleurobrachia pileus also showing elevated abundances. During the summer-fall period, A. digitale and Obelia spp. were less numerous, the species composition of hydromedusae tended to be slightly different from spring-summer (Figs. $3 \& 4$ ) and Beroe sp. was abundant especially in Korsfjord.

\section{DISCUSSION}

\section{Species composition and seasonal succession}

Meroplanktonic hydromedusae were most numerous during the summer, when several species appeared and reached peak abundances sequentially. The timing of the appearance of meroplanktonic hydromedusae in the water column is affected by the factors controlling the production and release of medusae by hydroids, such as light, temperature and food (Arai 1992). Unfortunately, the exact cues are so far unknown for most species (Mills 1993).

There were large differences in peak abundances reached by the various species. Several species of gelatinous zooplankton, including many meroplank- 
Table 2. Breakdown of average dissimilarity between Korsfjord and Fanafjord. Species accounting for the first $75 \%$ of the dissimilarity are shown in decreasing order of percentage contribution. Average abundances are given as ind. $1000 \mathrm{~m}^{-3}$. A high average dissimilarity to SD ratio (Diss:SD) implies that the species is a good discriminating species (Clarke \& Warwick 2001). The higher abundance (in Korsfjord vs. Fanafjord) for each species is in bold

\begin{tabular}{|lcccccc|}
\hline Species & $\begin{array}{c}\text { Korsfjord } \\
\text { Av. abund. }\end{array}$ & $\begin{array}{c}\text { Fanafjord } \\
\text { Av. abund. }\end{array}$ & Av. diss. & Diss:SD & Contrib. (\%) Cum. (\%) \\
\hline Dimophyes arctica & $\mathbf{2 6 5 . 4 4}$ & 4.51 & 5.64 & 1.95 & 9.43 & 9.43 \\
Aglantha digitale & 560.33 & $\mathbf{1 1 9 9 . 5 1}$ & 4.77 & 1.70 & 7.96 & 17.39 \\
Obelia spp. & 180.95 & $\mathbf{7 4 9 . 8 7}$ & 3.50 & 1.16 & 5.85 & 23.24 \\
Beroe sp. & $\mathbf{1 9 6 . 8 8}$ & 67.85 & 3.19 & 1.18 & 5.33 & 28.57 \\
Clytia hemisphaerica & 8.54 & $\mathbf{1 2 2 . 3 7}$ & 2.85 & 1.30 & 4.76 & 33.33 \\
Lensia conoidea & $\mathbf{2 0 1 . 4 0}$ & 37.59 & 2.44 & 1.23 & 4.07 & 37.41 \\
Indet. cydippid & 4.81 & $\mathbf{9 . 2 6}$ & 2.37 & 2.47 & 3.96 & 41.37 \\
Homoeonema platygonon & $\mathbf{5 . 7 2}$ & 0.38 & 2.18 & 2.28 & 3.64 & 45.01 \\
Euphysa aurata & 9.80 & $\mathbf{1 0 7 . 7 0}$ & 2.07 & 1.53 & 3.47 & 48.47 \\
Margelopsis hartlaubi & $\mathbf{2 2 . 2 0}$ & 3.05 & 1.95 & 1.21 & 3.26 & 51.73 \\
Rathkea octopunctata & 9.67 & $\mathbf{8 7 . 3 9}$ & 1.73 & 0.87 & 2.90 & 54.62 \\
Pleurobrachia pileus & 4.65 & $\mathbf{4 5 . 2 5}$ & 1.64 & 1.04 & 2.73 & 57.35 \\
Corymorpha nutans & 8.06 & $\mathbf{5 8 . 4 6}$ & 1.63 & 0.84 & 2.72 & 60.07 \\
Bougainvillia muscoides & 0.85 & $\mathbf{7 . 5 9}$ & 1.54 & 1.12 & 2.57 & 62.64 \\
Foersteria quadrata & $\mathbf{1 . 4 6}$ & 0.00 & 1.52 & 1.34 & 2.54 & 65.18 \\
Hydractinia areolata & 0.20 & $\mathbf{9 . 6 7}$ & 1.49 & 0.96 & 2.49 \\
Lizzia blondina & 1.03 & $\mathbf{2 7 . 9 7}$ & 1.47 & 0.70 & 2.46 & 77.66 \\
Dipurena gemmifera & 1.26 & $\mathbf{5 0 3 . 9 9}$ & 1.43 & 0.47 & 2.39 & 72.52 \\
& & & & & \\
\hline
\end{tabular}

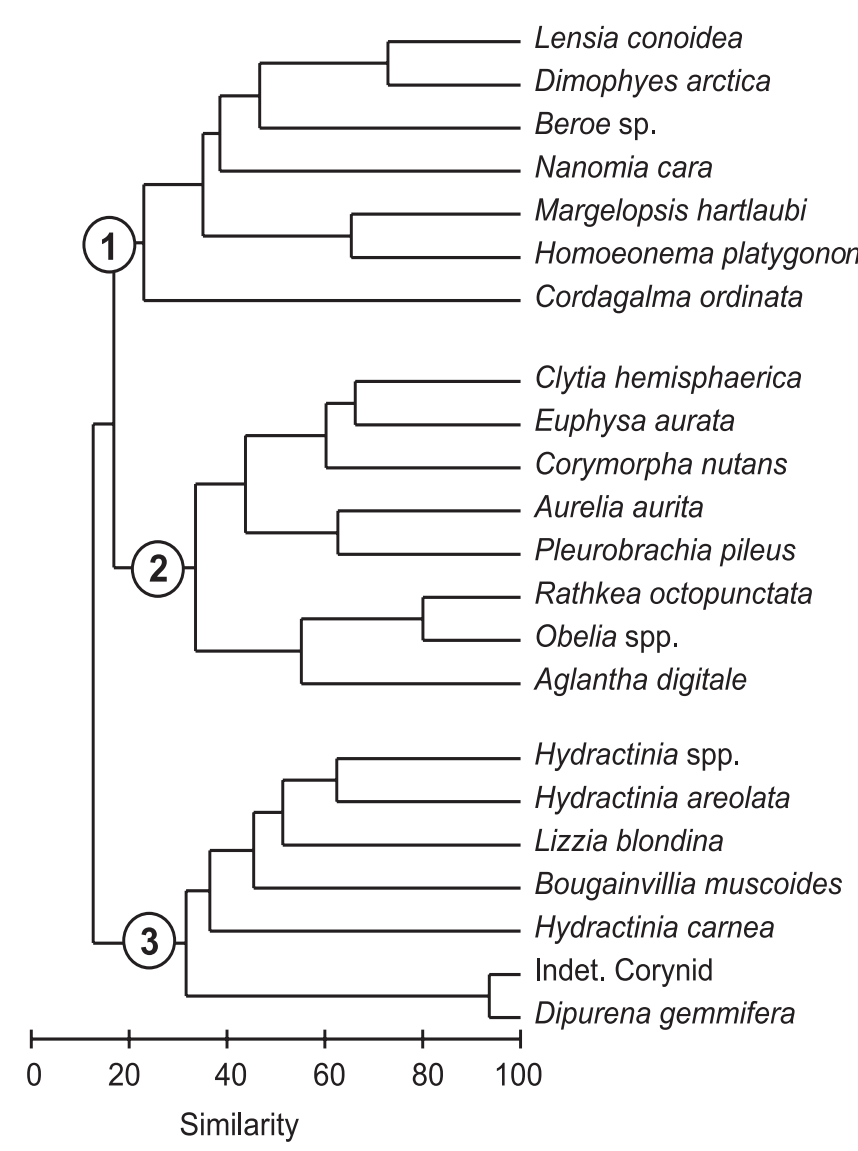

Fig. 10. Identified species associations. Hierarchical clustering with the 3 resulting groups at $20 \%$ similarity indicated tonic hydromedusae and diphyid siphonophores, are capable of rapid asexual reproduction, and their populations may thus respond quickly to favorable environmental conditions (Alldredge 1984). A case in point was the rise and fall of Dipurena gemmifera (was Sarsia gemmifera), which exhibited a massive increase in its abundance (and an even swifter disappearance) in August and September, especially in Fanafjord. The species is able to convert food into asexual reproductive output (medusae budded from the manubrium) within hours, facilitating a fast response to changing food availability. However, $D$. gemmifera is also strongly affected by low food levels, and thus requires relatively high prey concentrations for rapid population increase (Stibor \& Tokle 2003). The D. gemmifera bloom peaked in September, and was probably supported by the annual maximum of copepods in surface waters, which usually occurs around this time in Korsfjord and Fanafjord (Bjørke 1968, Matthews et al. 1996). Less than 3 wk after the observed peak density of 9.5 ind. $\mathrm{m}^{-3}$ in Fanafjord, $D$. gemmifera had completely disappeared from the water column. A similar seasonal pattern of occurrence was described by Kramp (1937, our translation follows), who wrote that '[D. gemmifera] appears in July, increases strongly in abundance through budding during the following 3 to $4 \mathrm{mo}$, after which it suddenly disappears'.

The hydromedusae also differed in terms of how long they persisted in the water column. Euphysa aurata was the only meroplanktonic medusa encoun- 

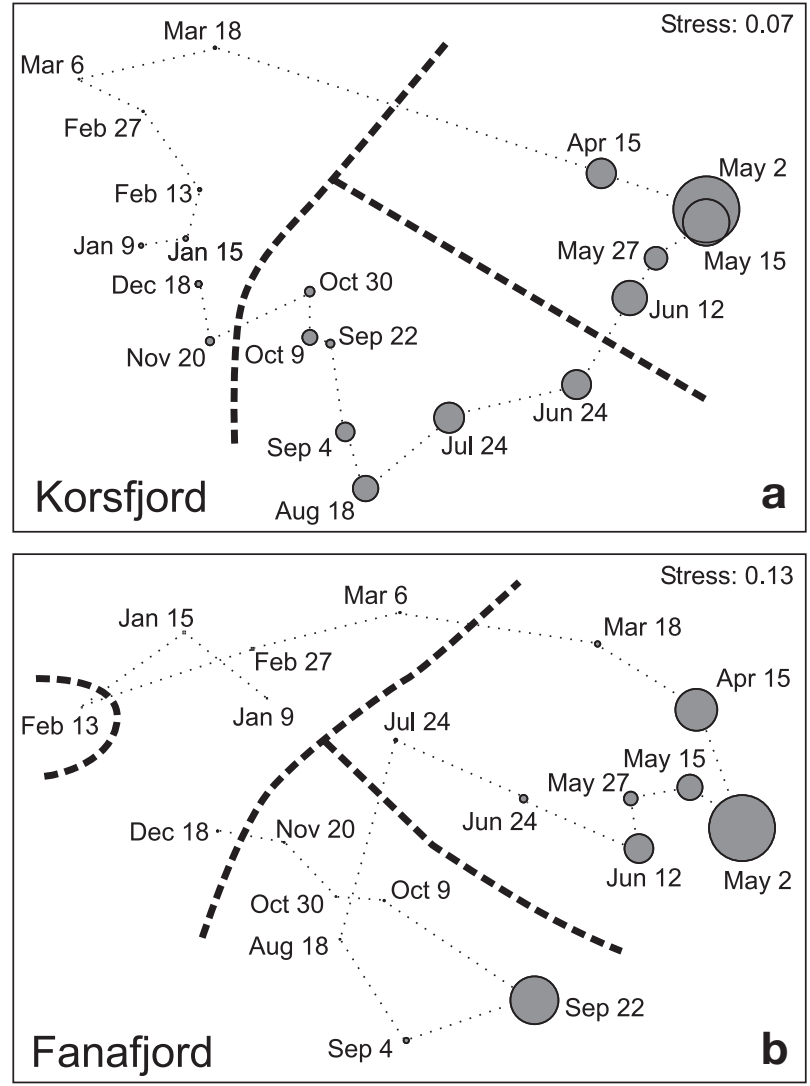

Fig. 11. Seasonal succession of gelatinous zooplankton in (a) Korsfjord and (b) Fanafjord. Superimposed bold hatched lines indicate hierarchical clustering (at $65 \%$ similarity level for Korsfjord and $40 \%$ similarity level for Fanafjord). Dotted line connecting the samples follows the chronological sequence of sampling. Bubble size is relative to abundance of gelatinous zooplankton within each fjord

tered in Korsfjord or Fanafjord at all times. E. aurata has also been found to occur throughout the year in the Mediterranean, with the assumption that the hydroids from deep, homeothermic habitats can produce medusae throughout the year without a seasonal temperature trigger (Goy 1991). Another species found in the plankton over extended periods of the year was Clytia hemisphaerica. According to Kramp (1937), C. hemisphaerica in Danish waters annually produces 2 medusoid generations that differ in form. The spring medusae live only a few weeks, become sexually mature at the size of 6 to $7 \mathrm{~mm}$ and reproduce during the same summer. The medusae produced later in the summer grow larger, overwinter and reproduce the following year. Lucas et al. (1995) reported that $C$. hemisphaerica in Southampton Water had a prolonged period of reproduction that was either continuous or with the production of distinct cohorts, depending on the year. In Fanafjord and Korsfjord, few overwintering $C$. hemisphaerica were observed, and these were not very large (Fig. 7). The largest average size was instead attained in early June. At least 2 distinct cohorts were produced during the summer and fall.

Factors contributing to the demise of meroplanktonic medusa populations include senescence, starvation, parasitism, disease and predation (Mills 1993). Changing food levels and prey composition can shift the competitive advantage from one species to another. For example, while Dipurena gemmifera is very good at exploiting high prey concentrations, it is also sensitive to low food levels (Stibor \& Tokle 2003). Intraguild predation is also common among hydromedusae and semaeostome scyphomedusae (Purcell 1991), and might be a factor in the seasonal succession of species. Rathkea octopunctata and Obelia spp. can constitute $>80 \%$ of Aurelia aurita prey during the spring months (Purcell 1991). Control of the R. octopunctata population by $A$. aurita has been suggested to occur in the Bedford Basin, where both species also ate large quantities of ctenophore and chaetognath eggs, possibly limiting their population development (Matsakis \& Conover 1991). Cyanea capillata feeds on A. aurita, and may exert control on its populations (Båmstedt et al. 1994). Of the siphonophores, Apolemia uvaria is known to frequently consume other gelatinous zooplankton (Purcell 1991). However, hydromedusae are selective feeders, and do not necessarily form a single guild competing for the same resources. Dissimilarities in the resource utilization by species may, for example, be related to differences in predation mode (Costello \& Colin 2002) or nematocyst type (Purcell \& Mills 1988).

The only holoplanktonic medusae observed in Korsfjord and Fanafjord were the Trachymedusae Aglantha digitale and Homoeonema platygonon. The latter, a deep-water species, was mostly encountered in Korsfjord. It is frequently observed in the deep fjords of western Norway, something which Kramp (1937) has attributed to advection from warmer waters. However, the consistent presence of $H$. platygonon in our samples makes us assume that it, like many other deepwater medusae, has a permanent population in the deep basin of Korsfjord.

\section{Aglantha digitale}

Populations of Aglantha digitale vary in terms of morphology (e.g. Kramp 1959) as well as life-cycle characteristics such as number of generations per year and size at maturity. A single generation has been reported in the Danish Straits and the North Sea (Kramp 1927, Nicholas \& Frid 1999), the White Sea (Pertsova et al. 2006) as well as the northeastern and northwestern Pacific (Arai \& Fulton 1973, Takahashi \& Ikeda 2006). Two generations occur in the southern 
Japan Sea (Ikeda \& Imamura 1996), a winter generation and 1 to 3 summer generations have been suggested for Oslofjord (Smedstad 1972) and up to 5 to 6 generations for the English Channel (Russell 1938), although the latter estimate has been criticized by Smedstad (1972) as too high. Our data indicate 1 main recruitment period in Korsfjord from March to May, with a second less pronounced reproduction by smaller females in early summer. The 2 reproductive events are evident in the bimodal size distribution as well as the 2 abundance peaks of $A$. digitale in Korsfjord and Fanafjord (Figs. 5 \& 6).

The main recruitment period obviously started in March (Figs. 5 \& 6), and the steady increase in average size and low size variability at each sampling time indicate the presence of a true cohort, growing from $0.1 \mathrm{~cm}$ bell height on 18 March to $1.3 \mathrm{~cm}$ on 24 July (Fig. 6). Applying the allometry equation $\log _{10} D W=$ $1.125\left(\log _{10} B H\right)^{2}+1.268 \log _{10} B H-2.333$, where $D W$ is dry weight and $B H$ bell height (Ikeda \& Imamura 1996), and then calculating the daily growth rate $G=$ $100 \times\left[\ln \left(D W_{\mathrm{t} 2} / D W_{\mathrm{t} 1}\right)\right] / t$, where $D W_{\mathrm{t} 2}$ and $D W_{\mathrm{t} 1}$ are from 24 July and 18 March, respectively, and $t$ is the number of days between the dates, gives a daily growth rate of $4.9 \% \mathrm{~d}^{-1}$, a realistic value for gelatinous zooplankton (cf. review by Arai 1997).

Since very few large, overwintering individuals were left at the time of the second peak (Figs. 5 \& 6), it is likely to represent a second generation rather than a second recruitment event by the overwintering generation. In cases with $>1$ annual generation, the summer generations have been found to reach maturity and spawn at a smaller size than the winter generation; Russell (1938) reported a 5 to $7 \mathrm{~mm}$ size at maturity, and Smedstad (1972) reported 6 to $8 \mathrm{~mm}$. A large proportion of the first-generation Aglantha digitale in Korsfjord and Fanafjord had reached this size range prior to the second peak, with a significant portion also having developed gonads (Fig. 5). Reproduction by $A$. digitale is followed by falling numbers of large individuals, indicating that spawning is followed by death (Arai \& Fulton 1973, Pertsova et al. 2006). The production of a second generation in June could thus explain the reduction in the number of animals between the 2 peaks as well as the concurrent dip in size distribution.

However, the bimodal size distribution observed early in the year as well as in June to August and the continued increase in the average size after the second reproductive event suggest that only part of the first generation spawns during the summer, giving rise to the second generation, while the rest grow on and overwinter at a larger size, only first reproducing the following spring. While a clearly bimodal size distribution was seen in January, the second generation spawned during the following summer seemed to dis- appear through late summer and fall, and no bimodal size distribution was observed at the end of the year. The strength and relative importance of the second generation thus seems to vary from year to year.

Rasmussen (1971) also observed young Aglantha digitale in Korsfjord after the initial spring spawning, in August and October. He also concluded that they could not have been spawned by the overwintering individuals, which were all but extinct by that time. However, he felt advection was a more likely explanation than further summer generations, since no large eggs had been observed in the gonads of larger individuals prior to the appearance of the small medusae in the fall. Unfortunately, we did not monitor the production of eggs.

The difference in the abundance of large individuals in Korsfjord between October 2004 and May 2005 (Fig. 8) is in agreement with the observed life cycle, whereas results for the adjacent Bjørnafjord indicate a high abundance of large individuals also in May, and thus suggest locally adapted life cycles. A prominent feature of all vertical profiles is the almost complete absence of large individuals above 200 to $250 \mathrm{~m}$ depth. With distribution mainly below the sill depth, the risk of advective transport out of the fjord system is reduced dramatically. However, with such a small number of transects, we only have a snapshot of the vertical distribution. Several studies have found that smaller Aglantha digitale specimens are generally found near the surface, but the maturing individuals penetrate to greater depth and are found deeper during the winter months (Russell 1938, Smedstad 1972, Williams \& Conway 1981, Pertsova et al. 2006), which is in agreement with our vertical distribution profiles. A. digitale is also known to perform diel vertical migrations (Arai \& Fulton 1973, Ikeda \& Imamura 1996, Pertsova et al. 2006), which was not accounted for in our study.

While Aglantha digitale was consistently present in Korsfjord, few were caught from Fanafjord during the winter months. The overwintering strategy of this species seems to be growth to a large size during autumn (Figs. 5 \& 6) and a vertical distribution below sill depth, where advective processes are minimal (Fig. 8). It is therefore probable that the shallow Fanafjord is not well suited as an overwintering habitat.

\section{Korsfjord vs. Fanafjord}

As far as the species composition was concerned, the differences between Korsfjord and Fanafjord arose not so much from different faunas, but from different relative abundances of the common species. Korsfjord was the more oceanic of the 2 fjords, with siphonophores 
occupying a prominent position. Fanafjord, on the other hand, was characterized by meroplanktonic Antho- and Leptomedusae, which generally require proximity to shallow, benthic environments for their sessile hydroid stage (Kramp 1959, Goy 1991). The difference in the number of observed species between the fjords may be partly attributed to the much larger total volume sampled from Korsfjord than from Fanafjord (40300 vs. $3400 \mathrm{~m}^{3}$ ) increasing the likelihood of encountering rare species. The probability of encountering visitors from outside the fjord is also larger in Korsfjord; for example, the sporadically collected siphonophores Agalma elegans, Apolemia uvaria and Sphaeronectes sp. were possibly advected to the fjord from outside. Indeed, almost all of the infrequently observed species were collected from Korsfjord.

However, there does seem to be a special community of deep-water medusae residing in the Korsfjord basin and lacking from the shallower Fanafjord. Many westNorwegian fjords contain basin water of Atlantic origin, resulting in relatively warm temperatures. Ptychogena crocea, Calycopsis simplex and Octophialucium funerarium are examples of deep-water medusae found in the warm bottom water of Norwegian fjords, but not on the continental shelf outside (Kramp 1959). Foersteria quadrata, Homoeonema platygonon, Margelopsis hartlaubi, Parateclaia norvegica, Modeeria rotunda and Bythotiara murrayi were also collected primarily from the deep stations of Korsfjord. Many of these deep-water species were only encountered sporadically, which may reflect either low abundances or, especially for benthopelagic species, that the gear we used was not well suited for collecting close to the bottom.

\section{Potential sources of error}

When comparing the abundances from Korsfjord and Fanafjord, it should be kept in mind that our net sampling did not allow for examination of vertical distribution. It has been demonstrated that many gelatinous species inhabit restricted depth ranges (Arai 1992, Graham et al. 2001). In the nearby Hardangerfjord, the bulk of the cnidarian community is found in the upper $50 \mathrm{~m}$ of the water column (Pagès et al. 1996). The densities in our study were calculated over the entire haul, so for animals occurring in distinct depth strata, the dilution with respect to the in situ maximum densities was several times larger for the deep Korsfjord than for the shallow Fanafjord. This may in some cases result in the erroneous conclusion that localized in situ densities were higher in Fanafjord than in Korsfjord, while the opposite might have been the case within the actual depth range occupied by a species. For example, several studies have noted that young Aglantha digitale are concentrated in the epipelagial during the summer months (Russell 1938, Smedstad 1972, Williams \& Conway 1981, Pertsova et al. 2006). Our density data, calculated over the entire water column, suggest that the average density of A. digitale at this time was higher in Fanafjord than in Korsfjord. However, the maximum number of specimens per sample was in fact higher in Korsfjord than in Fanafjord (average from Korsfjord stations on 2 May was 1867 specimens, vs. a maximum of 873 specimens collected at the Fanafjord station on 15 April). Assuming the animals were concentrated in the epipelagic, the resulting maximum density in Korsfjord would be more than twice the density in Fanafjord. The lack of vertical resolution in our data also presents problems for making comparisons with studies targeting specific depth strata.

Gelatinous zooplankton has notoriously patchy distributions, making it difficult to differentiate between population growth and its mere redistribution due to advection (Mills 1981, Arai 1992, Graham et al. 2001). In our study, this problem is somewhat alleviated by the semi-enclosed nature of the fjords, as well as the fact that several stations were sampled on each sampling date, allowing us to compare the situation at different locations. However, we cannot ignore the possibility that especially populations residing above sill depth may have been susceptible to advection to and from the fjord.

A higher sampling frequency would have provided better resolution with respect to population changes. Lifespans of most hydromedusae are probably on the scale of weeks to a few months (Arai 1992, Mills 1993), so a sampling frequency of 2 to $4 \mathrm{wk}$ means that we may theoretically have missed some short-lived species with a limited reproductive period entirely, or at least failed to spot their seasonal maximum. The short lifespan of many meroplanktonic hydromedusae, combined with their predominance in the Fanafjord samples, was probably part of the reason behind the larger differences observed in the species composition on different sampling dates in Fanafjord than in Korsfjord.

Last but not least, our study covered just 1 yr. We have no way of knowing whether the patterns we observed are representative of a typical year in the fjord system. Gelatinous zooplankton populations can exhibit significant interannual differences in terms of abundance (Lucas et al. 1995, Nicholas \& Frid 1999, Ballard \& Myers 2000) and relative importance as predators (Nicholas \& Frid 1999). Special hydrographic conditions can also affect the distribution and abundance of gelatinous fauna (Raskoff 2001, Lynam et al. 2004), and have sometimes led to the advection of 
large populations of exotic gelatinous organisms into Norwegian waters (e.g. Båmstedt et al. 1998, Fosså et al. 2003). The strikingly different size distributions of the dominant Aglantha digitale at the beginning versus the end of the year suggest that interannual variations are also significant for the gelatinous community of Korsfjord and Fanafjord.

Acknowledgements. This study was supported by the Research Council of Norway (project no. 146994/120) and the Finnish Cultural Foundation. We thank the crew of RV 'Brattström', M. Martinussen and T. Sørlie for help during sampling. F. Pagès helped confirm the identification of some tricky specimens. Comments by C. Schander, J. Titelman and the reviewers significantly improved the paper. The assistance of H. Savolainen in counting the plankton samples is much appreciated.

\section{LITERATURE CITED}

Alldredge AL (1984) The quantitative significance of gelatinous zooplankton as pelagic consumers. In: Fasham MJR (ed) Flows of energy and materials in marine ecosystems: theory and practice. Plenum Press, London, p 407-433

Arai MN (1992) Active and passive factors affecting aggregations of hydromedusae: a review. Sci Mar 56:99-108

Arai MN (1997) A functional biology of Scyphozoa. Chapman \& Hall, London

Arai MN, Fulton J (1973) Diel migration and breeding cycle of Aglantha digitale from two locations in the northeastern Pacific. J Fish Res Board Can 30:551-553

Bakke JLW, Sands NJ (1977) Hydrographical studies of Korsfjorden, Western Norway, in the period 1972-1977. Sarsia 63:7-16

Ballard L, Myers A (2000) Observations on the seasonal occurrence and abundance of gelatinous zooplankton in Lough Hyne, Co. Cork, South-West Ireland. Biol Environ Proc R Ir Acad B 100:75-83

Båmstedt U, Youngbluth M (2000) Norwegian marine science goes deeper. Ocean Chall 9:25-30

Båmstedt U, Martinussen MB, Matsakis S (1994) Trophodynamics of the two scyphozoan jellyfishes, Aurelia aurita and Cyanea capillata, in western Norway. ICES J Mar Sci 51: 369-382

Båmstedt U, Fosså JH, Martinussen MB, Fosshagen A (1998) Mass occurrence of the physonect siphonophore Apolemia uvaria (Lesueur) in Norwegian waters. Sarsia 83:79-85

Behrends G, Schneider G (1995) Impact of Aurelia aurita medusae (Cnidaria, Scyphozoa) on the standing stock and community composition of mesozooplankton in the Kiel Bight (western Baltic Sea). Mar Ecol Prog Ser 127: 39-45

Bjørke H (1968) Zooplankton i Grimseidpollen og Fanafjorden. MS thesis, University of Bergen

Bouillon J, Medel MD, Pagès F, Gili JM, Boero F, Gravili C (2004) Fauna of the Mediterranean hydrozoa. Sci Mar 68: $5-438$

Carré C (1968) Contribution à l'étude du genre Sphaeronectes Huxley, 1859. Vie Milieu Ser A Biol Mar 19:85-94

Clarke KR, Warwick RM (2001) Change in marine communities: an approach to statistical analysis and interpretation, 2nd edn. PRIMER-E, Plymouth
Costello JH, Colin SP (2002) Prey resource use by coexistent hydromedusae from Friday Harbor, Washington. Limnol Oceanogr 47:934-942

Fosså JH, Flood PR, Olsen AB, Jensen F (2003) Små og usynlige, men plagsomme maneter av arten Muggiaea atlantica. Fisk Havet 2:99-103

Goy J (1991) Hydromedusae of the Mediterranean Sea. Hydrobiologia 216-217:351-354

Graham WM, Pagès F, Hamner WM (2001) A physical context for gelatinous zooplankton aggregations: a review. Hydrobiologia 451:199-212

Hosia A, Pagès F (2007) Unexpected new species of deepwater Hydroidomedusae from Korsfjorden, Norway. Mar Biol 151:177-184

Ikeda T, Imamura A (1996) Abundance, vertical distribution and life cycle of a hydromedusa Aglantha digitale in Toyama Bay, southern Japan Sea. Bull Plankton Soc Jpn 43: 31-43

Kramp PL (1927) The hydromedusae of the Danish waters. K Dan Vidensk Selsk Skr 8:1-291

Kramp PL (1937) Polypdyr (Coelenterata) II. Gopler. GEC Gads Forlag, Copenhagen

Kramp PL (1959) The hydromedusae of the Atlantic Ocean and adjacent waters. Dana Report 46:1-283

Kramp PL, Damas D (1925) Les méduses de la Norvège. Vidensk Medd Dan Nathist Foren 80:217-323

Lucas CH, Williams DW, Williams JA, Sheader M (1995) Seasonal dynamics and production of the hydromedusan Clytia hemisphaerica (Hydromedusa: Leptomedusa) in Southampton Water. Estuaries 18:362-372

Lynam CP, Hay SJ, Brierly AS (2004) Interannual variability in abundance of North Sea jellyfish and links to the North Atlantic Oscillation. Limnol Oceanogr 49:637-643

Matsakis S, Conover RJ (1991) Abundance and feeding of medusae and their potential impact as predators on other zooplankton in Bedford Basin (Nova Scotia, Canada) during spring. Can J Fish Aquat Sci 48:1419-1430

Matthews JBL, Sands NJ (1973) Ecological studies on the deep-water pelagic community of Korsfjorden, western Norway: the topography of the area and its hydrography in 1968-1972, with a summary of the sampling programmes. Sarsia 52:29-52

Matthews JBL, Heimdal BR, Torp UMF (1996) Hydrography and cycle of phytoplankton and zooplankton in fjord and coastal waters of western Norway. IFM Rapp 10:1-62

Mills CE (1981) Seasonal occurrence of planktonic medusae and ctenophores in the San Juan archipelago (NE Pacific). Wasmann J Biol 39:6-29

Mills CE (1993) Natural mortality in NE Pacific coastal hydromedusae: grazing predation, wound-healing and senescence. Bull Mar Sci 53:194-203

Nicholas KR, Frid CLJ (1999) Occurrence of hydromedusae in the plankton off Northumberland (western central North Sea) and the role of planktonic predators. J Mar Biol Assoc UK 79:979-992

Pagès F, Gonzáles HE, Gonzáles SR (1996) Diet of the gelatinous zooplankton in Hardangerfjord (Norway) and potential predatory impact by Aglantha digitale (Trachymedusae). Mar Ecol Prog Ser 139:69-77

Pertsova NM, Kosobokova KN, Prudkovsky AA (2006) Population size structure, spatial distribution, and life cycle of the hydromedusa Aglantha digitale (O.F. Müller, 1766) in the White Sea. Oceanology 46:228-237

Purcell JE (1991) A review of cnidarians and ctenophores feeding on competitors in the plankton. Hydrobiologia 216-217:335-342

Purcell JE, Mills CE (1988) The correlation between nemato- 
cyst types and diets in pelagic hydrozoa. In: Hessinger DA, Lenhoff HM (eds) The biology of nematocysts. Academic Press, San Diego, CA

Raskoff KA (2001) The impact of El Niño events on populations of mesopelagic hydromedusae. Hydrobiologia 451:121-129

Rasmussen RE (1971) Om biologien til Aglantha digitale (O. F. Müller) med bemerkninger om forekomsten av de övrige hydromeduser i Korsfjorden, Vest Norge. MS thesis, University of Bergen

Rees WJ (1952) Records of hydroids and medusae taken at Herdla, Bergen in 1937. Universitet i Bergen årbok. Naturvitenskapelig Rekke 16:1-8

Runnström S (1931) Eine Übersicht über das Zooplankton des Herdla- und Hjeltefjordes. Bergen Museums Årbok. Naturvidenskapelig Rekke 7:1-67

Russell FS (1938) The Plymouth offshore medusa fauna. J Mar Biol Assoc UK 22:411-439

Schneider G, Behrends G (1998) Top-down control in a neritic plankton system by Aurelia aurita medusae: a summary. Ophelia 48:71-82

Editorial responsibility: Otto Kinne (Editor-in-Chief), Oldendorf/Luhe, Germany
Smedstad OM (1972) On the biology of Aglantha digitale rosea (Forbes) [Coelenterata: Trachymedusae] in the Inner Oslofjord. Nor J Zool 20:111-135

Stibor H, Tokle N (2003) Feeding and asexual reproduction of the jellyfish Sarsia gemmifera in response to resource enrichment. Oecologia 135:202-208

Takahashi D, Ikeda T (2006) Abundance, vertical distribution and life cycle patterns of the hydromedusa Aglantha digitale in the Oyashio region, western subarctic Pacific. Plankton Benthos Res 1:91-96

Verity PG, Smetacek V (1996) Organism life cycles, predation, and the structure of marine pelagic ecosystems. Mar Ecol Prog Ser 130:277-293

Wassmann P (1984) Sedimentation and benthic mineralization of organic detritus in a Norwegian fjord. Mar Biol 83: 83-94

Williams R, Conway DVP (1981) Vertical distribution and seasonal abundance of Aglantha digitale (O. F. Müller) (Coelenterata: Trachymedusae) and other planktonic coelenterates in the northeast Atlantic Ocean. J Plankton Res 3:633-643

Submitted: January 18, 2007; Accepted: July 9, 2007

Proofs received from author(s): November 14, 2007 